\title{
ITSN protein family: Regulation of diversity, role in signalling and pathology
}

\author{
L. O. Tsyba, M. V. Dergai, I. Ya. Skrypkina, O. V. Nikolaienko, \\ O. V. Dergai, S. V. Kropyvko, O. V. Novokhatska, D. Ye. Morderer,
}

T. A. Gryaznova, O. S. Gubar, A. V. Rynditch

Institute of Molecular Biology and Genetics, NAS of Ukraine

150, Akademika Zabolotnoho Str., Kyiv, Ukraine, 03680

1.o.tsyba@imbg.org.ua

\begin{abstract}
Adaptor/scaffold proteins of the intersectin (ITSN) family are important components of endocytic and signalling complexes. They coordinate trafficking events with actin cytoskeleton rearrangements and modulate the activity of a variety of signalling pathways. In this review, we present our results as a part of recent findings on the function of ITSNs, the role of alternative splicing in the generation of ITSN1 diversity and the potential relevance of ITSNs for neurodegenerative diseases and cancer.
\end{abstract}

Keywords: adaptor/scaffold proteins, intersectin family, alternative splicing, endocytosis.

Introduction. Adaptor/scaffold proteins are important components of many cellular processes and signalling systems. Classical scaffolds typically do not posses any enzymatic activity. They function as platforms for the assembly of multiprotein complexes and can help to localize signalling molecules to a specific compartment of the cell or/and regulate the efficiency of a signalling pathway $[1,2]$.

Scaffold proteins may both facilitate or inhibit signal transduction depending on their concentration in certain compartments, regulating the strength, specificity and duration of signal propagation.

Adaptor/scaffold proteins of intersectin (ITSN) family are characterized by the presence of multiple domains that mediate protein-protein interactions. By binding to numerous proteins, ITSNs assemble multimeric complexes implicated in clathrin- and caveolin-mediated endocytosis, actin cytoskeleton rearrangements, cell signalling and survival (reviewed in [3, 4]). Abnormalities of expression of the ITSN1 gene, which is located

(C) Institute of Molecular Biology and Genetics, NAS of Ukraine, 2013 on chromosome 21 , were associated with the endocytic anomalies reported in patients with Down syndrome and Alzheimer's disease [5-7].

In this review, we present our results and summarize recent findings of other laboratories concerning the role of ITSN family members in the formation of clathrin-coated vesicles and regulation of signal transduction and actin cytoskeleton rearrangements. We also describe the impact of alternative processing on the generation of diversity of the ITSN family and regulation of the ITSN genes expression.

Role of ITSN in endocytosis and signalling. ITSN family consists of proteins encoded by two genes, ITSN1 and ITSN2, located on human chromosomes 21 and 2, respectively $[8,9]$. ITSN1 and ITSN2 are evolutionarily conserved proteins and have the same domain organization. The short isoform (ITSN-S) consists of two Eps15 homology domains (EH1 and EH2), a coiledcoil region (CCR) and five Src homology 3 domains (SH3A-E). The long isoform (ITSN-L) contains an extended C-terminus consisting of a Dbl homology (DH), a Pleckstrin homology $(\mathrm{PH})$ and a $\mathrm{C} 2$ domain. 


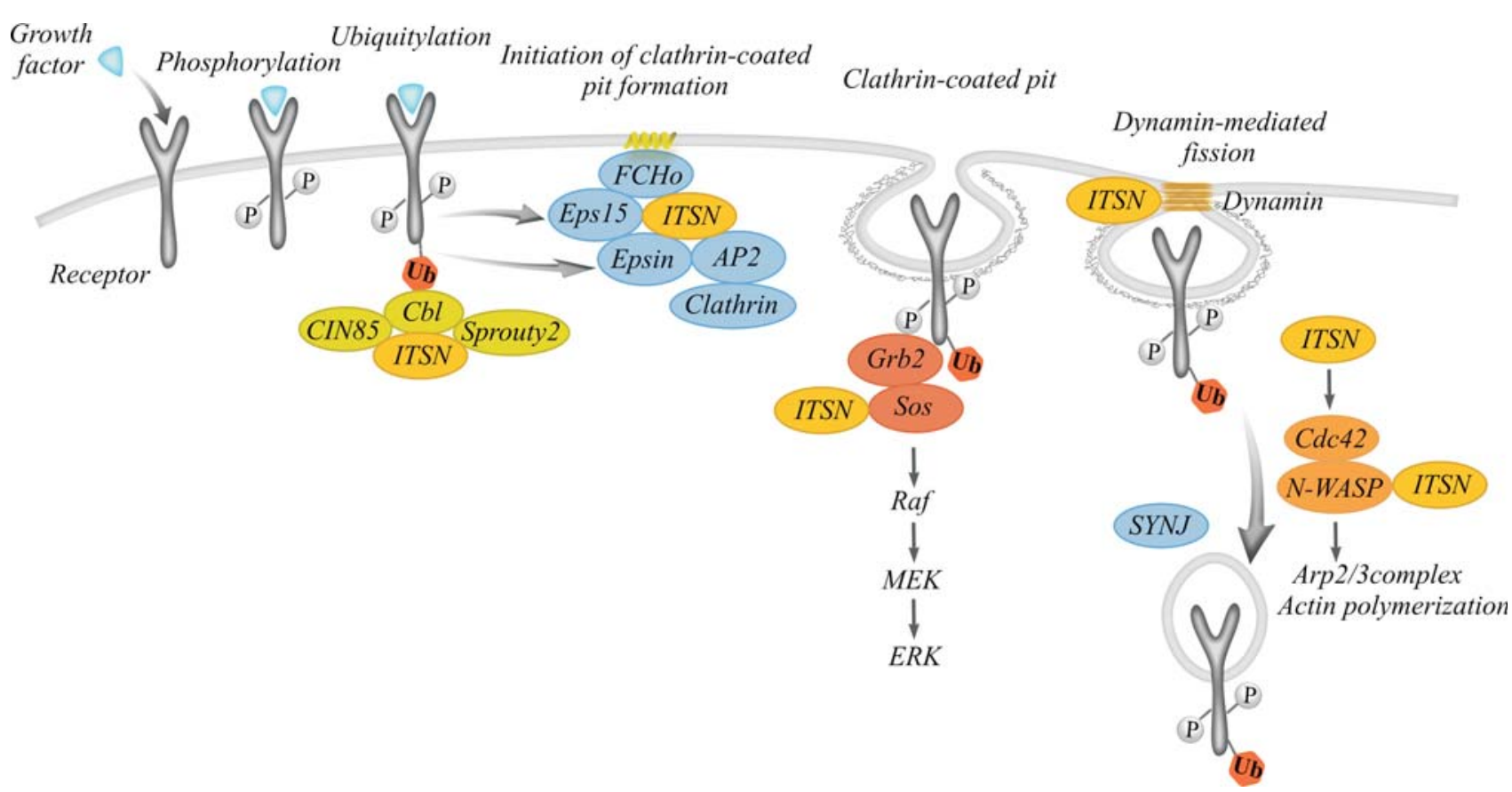

Fig. 1. ITSNs are important components of clathrin-mediated endocytosis and signalling. Upon ligand binding, plasma membrane signalling receptors such as receptor tyrosine kinases undergo dimerization, auto-phosphorylation and ubiquitylation. Ubiquitylated receptors are recognized by adaptors, such as Eps 15 and epsin, and recruited to clathrin-coated pits. After vesicle scission, receptors undergo sorting and are either recycled back to the plasma membrane or directed to lysosomes for degradation

The DH domain is the only catalytic domain in ITSNs. It possesses guanine nucleotide exchange activity specific for the small GTPase Cdc42 [10]. Our data indicate that the DH domain of ITSN2 regulates the activity of Cdc42 during embryo development affecting actin cytoskeleton in Xenopus embryos. Overexpression of the $\mathrm{DH}$ and $\mathrm{PH}$ domains in Xenopus embryos resulted in aberrant phenotypes [11]. Embryos displayed hyperpigmentation and gastrulation failure that were incompatible with survival. The effect of expression of the constitutively active Cdc42 strongly resembled that of the DH-PH tandem. Moreover, the dominant negative Cdc42 partially rescued the developmental defects induced by the expression of the DH-PH domains [11]. ITSN2 was reported to regulate $\mathrm{Cdc} 42$ activation during epithelial morphogenesis. Silencing of either Cdc42 or ITSN2 disrupted the proper orientation of the mitotic spindle and normal lumen formation [12]. Guanine nucleotide exchange activity of the brain-enriched ITSN1-L isoform was shown to be important for dendritic spine morphogenesis [13, 14].

ITSN1 was shown to act at different stages of clathrin-mediated endocytosis (Fig. 1). It forms complexes with a plethora of endocytic proteins including the scaffolding adaptor Eps 15 [15], large GTPase dynamin involved in vesicle fission, a phosphoinositide phosphatase synaptojanin 1 [16], endocytic accessory protein epsin [17] and others. The $\alpha$ - and $\beta$-appendage domains of clathrin adaptor complex AP2 were shown to directly interact with the linker between the SH3A and SH3B domains of ITSN1 [18]. Our results demonstrate the interaction of ITSN1 with a membrane-deforming protein SGIP1 and their colocalization in clathrin-coated pits [19].

The role of ITSN1 as an important endocytic scaffold has been confirmed by studies on Drosophila Dap 160 (homolog of human ITSN)-null mutants, which display severely reduced levels of dynamin, synaptojanin, endophilin and AP180 in Dap160 mutant synapses, suggesting the role of Dap160 in recruitment of endocytic proteins to the presynaptic terminals [20,21]. A reduced number of exocytosis events in chromaffin cells and a slowing of endocytosis in neurons were also detected in ITSN1 null mice [22].

Initially, the role of ITSN1 in clathrin-mediated endocytosis was thought to be restricted to the invagination and fission stages [15]. Recently, ITSNs and Eps15 were shown to be necessary for initiation of cla- 
thrin-coated pit assembly. It was found that ITSNs and Eps15 regulate clustering of membrane-sculting proteins FCHo, which mark the sites of clathrin-coated pits formation and act as clathrin-coated pit nucleators [23] (Fig. 1).

ITSN1 is also an important component of the exocytic machinery. ITSN1 interacts with SNAP-25 [16], a protein of the SNARE complex that is critical for the docking and fusion of secretory granules to the plasma membrane. Moreover, the DH domain of ITSN1-L is important for the actin cytoskeletal rearrangements required for exocytosis in neuroendocrine cells [24]. Silencing of ITSN1 strongly inhibited exocytosis and simultaneously prevented secretagogue-induced activation of Cdc42. ITSN1-L has been proposed to couple Cdc42mediated actin remodelling involved in the late stages of exocytosis with the recruitment of the endocytic machinery required for the subsequent compensatory endocytosis in secretory cells [25].

Endocytosis is a critical component in membrane receptor signalling. Although endocytosis terminates receptor signalling [26], it also has emerged as an essential step in the successful activation of receptor-dependent signalling pathways $[27,28]$. Very recently, it has been shown that inhibition of early stages of clathrin-mediated endocytosis, by knockdown of ITSN2 or clathrin heavy chain, attenuated granulocyte-macrophage colony stimulating factor receptor (GMR)-mediated signalling, whereas inhibition of the membrane constriction step during clathrin-coated vesicle formation enhanced GMR signalling. Moreover, an ITSN2-non-binding mutant of GMR defective in targeting to clathrin-coated pits failed to activate JAK2 kinase [29].

Several experimental data suggest that ITSNs are one of the key molecules that link endocytosis and signal transduction. We and other laboratories have demonstrated that ITSN1 through its SH3 domains forms complexes with E3-ubiquitin ligases of Cbl family [3032] as well as with Sprouty 2, a negative regulator of $\mathrm{Cbl}$ [33, 34] (Fig. 1). These interactions lead to enhancing Cbl-mediated ubiquitylation and degradation of epidermal growth factor receptor (EGFR) [30, 33]. Moreover, our recent results demonstrate that ITSN1 forms a stable complex with scaffolding protein Ruk/CIN85 that regulates recruiting the Cbl-EGFR complex to endosomes for downregulation of receptor tyrosine kinase, as well as is involved in cytoskeletal rearrangements and apoptosis [35]. CIN85/ITSN1/Cbl-b complexes were found to be localized in clathrin-coated pits [31].

Recently, it was shown that interaction of ITSN1 with endocytic adaptor Dab2 was important for internalization of integrin $\beta 1$, a specific cargo for Dab2 adaptors [36]. It was demonstrated that downregulation of ITSN1 via siRNA inhibits Erk1/2-MAPK and its direct activator MEK and leads to mitochondrial apoptosis of cultured human lung microvascular endothelial cells [37]. Downregulation of ITSN1 expression in mouse lungs by siRNA in vivo treatment caused endothelial cells death and lung injury, followed by endothelial phenotypic changes regarding hyper-proliferation and apoptosis-resistance [38].

ITSN1 was also shown to regulate the survival of neuronal cells through the activation of the PI3K-AKT pathway by interaction with $\mathrm{PI} 3 \mathrm{~K}-\mathrm{C} 2 \beta$. Decreasing ITSN expression by shRNA inhibited the PI3K-C2 $\beta-$ AKT signalling pathway and dramatically increased apoptosis in both neuroblastoma cells and primary cortical neurons [39].

Recently, the results of yeast two-hybrid screen for proteins that bind ITSNs were published. It was found 127 potential ITSN-binding proteins involved in the membrane curvature, several cellular pathways including Rab and Arf GTPase regulation, receptor tyrosine kinase regulation, and inositol phosphate/phosphatidylinositol metabolism [40]. Several nuclear proteins including RNA binding proteins and transcription factors were found to be potential ITSN partners. Therefore, additional studies are needed for complete understanding ITSN-interacting network.

Alternative splicing and alternative transcription of ITSN1. Two major ITSNs isoforms are produced by alternative splicing of exon 30 that provides the termination codon for the short isoform. Recently, we and others identified additional splicing events affecting ITSNs mRNA and binding properties of the corresponding protein isoforms.

Four evolutionarily conserved in-frame alternative splicing events affecting ITSN1 mRNAs were found in mice and humans $[9,16,41]$ (Fig. 2). These events include:

(1) the use of an alternative 3'-splice site internal to exon 6 that results in truncation of exon 6 and deletion 


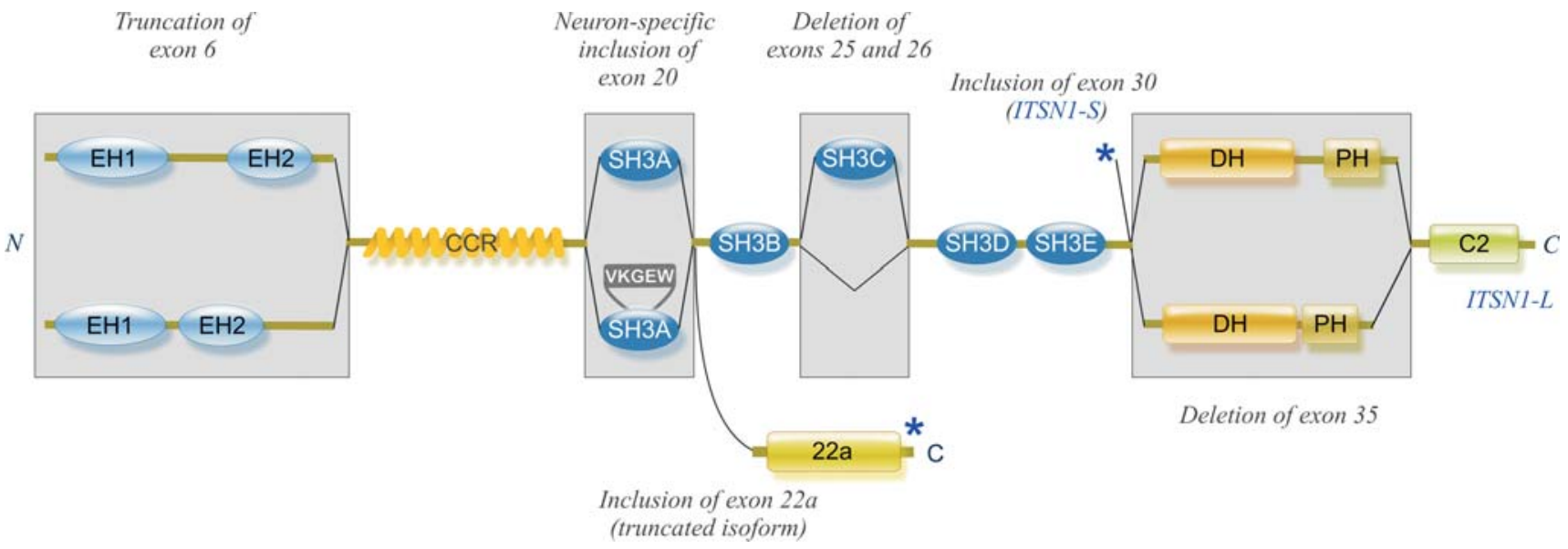

Fig. 2. Schematic representation of alternative splicing events affecting human ITSN1. Asterisk indicates a stop codon

of 37 amino acids between the EH1 and EH2 domains. Approximately $3 \%$ of ITSN1 transcripts contain a truncated exon 6 [42];

(2) splicing of the neuron-specific exon 20 that encodes 5 amino acids in the SH3A domain. ITSN1 transcripts containing exon 20 were detected only in neurons. The expression of such transcripts is developmentally regulated $[41,43]$. The frequency of the + exon 20 variant of ITSN1 increases during fetal brain development whereas the level of the transcript lacking exon 20 decreases respectively;

(3) skipping of exons 25 and 26 that encode the SH3C domain. The ratio of ITSN1 isoforms with and without exons 25 and 26 varies in fetal and adult brain $[9,41]$. In other tissues about $20 \%$ of all ITSN1 transcripts lack exon 25 and 26 [42];

(4) skipping of exon 35 encoding 31 amino acids of the DH domain and 25 residues of the DH-PH interdomain linker. Skipping of exon 35 occurs in approximately $10 \%$ of ITSN1-L isoforms, but the ratio of ITSN1-L transcripts with and without exon 35 differs in brain and other tissues.

We also found ITSN1 isoform with an alternative Cterminus, which is encoded by exon 22a [44]. Inclusion of exon 22a results in the generation of the shortest ITSN1 transcript (ITSN1-22a) that encodes a protein containing two EH domains, coiled-coil region, SH3A domain and specific $\mathrm{C}$ terminal domain (CTD). ITSN122a binds via its CTD to the SH3 domain of the endocytic protein amphiphysin 1 and the SH3A domain of ITSN1. We demonstrated intramolecular interaction wi- thin ITSN1-22a that negatively regulates its association with the ubiquitin ligase $\mathrm{Cbl}$ [44].

Different combinations of splicing events described above could generate 16 variants of the ITSN1-L, 8 variants of the short ITSN1 isoforms and 4 variants of the ITSN1-22a isoforms. We cloned all eight variants of ITSN1-S [42].

Although the function of the most alternatively spliced isoforms of ITSNs are poorly understood, the role of alternative splicing was clearly demonstrated in case of the ITSN1 microexon 20 splicing that provides a mechanism for tissue-specific control of protein-protein interactions. Using mutational analysis, we found that neuron-specific insertion of a microexon 20 regulates of the SH3A domain specificity due to the shifting of negatively charged amino acids towards the interaction interface [45].

The neuron-specific isoform of SH3A domain binds with significantly higher affinity the endocytic proteins dynamin 1 and synaptojanin 1, as well as the GTPaseactivating protein CdGAP, while the ubiquitously expressed isoform preferentially interacts with the signalling proteins Sos1 and Cbl [43].

In our experiments we detected multiple splicing events that cause frameshifts in ITSN1 mRNA and introduce premature termination codons that lie more than 50 nucleotides upstream of an exon-exon junction [41, 42]. Such mRNAs are expected to be degraded via the nonsense-mediated mRNA decay (NMD) pathway [46]. The relatively high abundance of mRNAs with premature termination codons suggests the participation of alter- 
native splicing and NMD in regulation of the expression level of ITSN1.

We also detected the ITSN1 transcripts produced from an alternative promoter of the human ITSN1 gene, which is located in intron 5. These transcripts contain in-frame ATG codon with strong Kozak sequence and could encode N-terminally truncated isoforms lacking first EH domain. Such transcripts were detected in human kidney, liver, lung and brain tissues. However, the level of their expression was significantly lower than that of the major ITSN1 isoforms. The region located 246-190 bp upstream of exon 6 was found to be required for alternative promoter activity [47].

Role of ITSNs in diseases. ITSN1 was shown to be associated with the development of several pathologies that affect the nervous system. The ITSNI gene is mapped to human chromosome 21 and its expression is upregulated in patients with Down syndrome (DS) $[5,48$, 49]. As association between endocytic abnormalities and pathological processes of DS and early stages of Alzheimer's disease was clearly stated, ITSN1 was considered to be associated with these disorders $[3,7]$. Recently reported transgenic mouse model, in which ITSN1-S is specifically overexpressed in the forebrain, exhibited specific behavioral phenotypes and sex-dependent decrease in locomotor activity [5].

ITSN1-S was shown to increase aggregation of mutant huntingtin during Huntington's disease through activation of the JNK-MAPK pathway [50]. Furthermore, ITSN1 was identified as a binding partner for DISC1 (disrupted in schizophrenia 1) suggesting a potential role in psychiatric disease as well [40]. Recently, we have identified a stable tubule-only polypeptide (STOP) as an ITSN1-binding protein using affinity chromatography followed by MALDI-TOF mass spectrometry.

STOP and ITSN1 were shown to form a complex in vivo and to co-localize partially in rat primary hippocampal neurons [51]. STOP is a microtubule-stabilizing protein that is required for several forms of synaptic plasticity in the hippocampus [52]. It is widely accepted that synaptic plasticity is a physiological mechanism of memory and cognition that is often disrupted in mental disorders. Elucidation of the functional significance of ITSN1-STOP interaction in neurons is a challenge for future research.
During evolution, viruses have developed different mechanisms for manipulation of host signalling pathways to establish optimal conditions for their replication and survival. Signalling and regulatory molecules are preferentially targeted by pathogens because they globally regulate many cellular processes [53]. Last year we reported that latent membrane protein $2 \mathrm{~A}$ (LMP2A) of Epstein-Barr virus interacts with ITSN1 and regulates its phosphorylation [54]. The interaction occurs directly via $\mathrm{C}$-terminal proline-rich motifs and can be mediated by the Shb adaptor protein. Shb interacts simultaneously with the phosphorylated tyrosines of LMP2A and the SH3 domains of ITSN1 and mediates indirect binding of ITSN1 to LMP2A. We have shown that Syk kinase promotes phosphorylation of both ITSN1 and Shb adaptors in LMP2A-expressing cells [54].

These results indicate that LMP2A can affect a number of host cell signalling pathways by regulating the phosphorylation of the ITSN1 and Shb adaptors.

Given the role of ITSN in the activation of mitogenic pathways, its involvement in cancer development was proposed. It was shown that siRNA-mediated down regulation of ITSN1 induced apoptosis, inhibited migration and invasion of glioma cells $[55,56]$. Russo and O'Bryan [57] reported that silencing of ITSN1 in neuroblastoma cell lines reduced their anchorage independent growth and tumor formation in a xenograft model.

However, these effects were not associated with increasing of apoptosis in ITSN1-silenced neuroblastoma cell lines [57].

ITSN2 was found in gene signature that predicts disease recurrence in breast cancer patients after adjuvant chemotherapy with cyclophosphamide, methotrexate and 5-fluorouracil. High expression level of ITSN2 was associated with prolonged disease-free survival [58]. We analyzed expression of short and long ITSN2 isoforms in breast tumors. The lowest level of ITSN2 expression, especially ITSN2-S isoform, was detected in estrogen/progesterone receptor-negative, HER2/neu-positive tumors with poor prognosis and in estrogen/progesterone receptor-positive tumors of patients with lymph node metastasis. Amount of ITSN2L did not differ significantly in breast tumors analyzed [59]. 
Taking together, the results of last decade have established the role of ITSNs as scaffolding molecules that regulate the assembly of endocytotic proteins at the sites of endocytosis, coordinate interaction of endocytic complexes with signalling molecules and regulate Cdc42-mediated actin dynamics. Future studies may shed new insight into the role of these scaffolds in diseases, especially in cancer and neurodegenerative pathologies.

Still, the open question is the mechanism of regulation of ITSNs functioning in different cell types, especially the role of posttranslational modifications.

Л. О. Циба, М. В. Дергай, І. Я. Скрипкіна, О. В. Ніколаєнко, О. В. Дергай, С. В. Кропивко, О. В. Новохаиька, Д. С. Мордерер, Т. А. Грязнова, О. С. Губар, А. В. Риндич

Родина білків ITSN: регуляція різноманіття ізоформ, роль у передачі внутрішньоклітинних сигналів та зв'язок 3 патологіями

Резюме

Адапторні білки родини інтерсектинів (ITSN) є важливими компонентами ендоцитозних і сигнальних комплексів. Вони координують внутрішньоклітинний трафік і перебудови актинового иитоскелета та модулюють активність різних сигнальних шляхів. В огляді представлено результати наших досліджень, а також дані інших лабораторій стосовно функиії ITSN, ролі альтернативного сплайсингу у формуванні різноманіття ізоформ ITSN1 $i$ зв 'язку інтерсектинів з нейродегенеративними хворобами та злоякісними пухлинами.

Ключові слова: адапторні білки, родина інтерсектинів, альтернативний сплайсинг, ендоцитоз.

Л. А. Цыба, Н. В. Дергай, И. Я. Скрипкина, А. В. Николаенко, А. В. Дергай, С. В. Кропивко, О. В. Новохаикая, Д. Е. Мордерер, Т. А. Грязнова, О. С. Губарь, А. В. Рындич

Семейство белков ITSN: регуляция разнообразия изоформ, роль в передаче внутриклеточных сигналов и связь с патологиями

Резюме

Адапторные белки семейства интерсектинов (ITSN) - важные компоненты эндоцитозных и сигнальных комплексов. Они координируют внутриклеточный трафик и перестройки актинового цитоскелета, а также модулируют активность различных сигнальных путей. В обзоре представлены результаты наших исследований и данные других лабораторий относительно функиии ITSN, роли альтернативного сплайсинга в формировании разнообразия изоформ ITSN1 и связи интерсектинов с нейродегенеративными заболеваниями и злокачественными опухолями.

Ключевые слова: адапторные белки, семейство интерсектинов, альтернативный сплайсинг, эндоцитоз.

\section{REFERENCES}

1. Zeke A., Lukacs M., Lim W. A., Remenyi A. Scaffolds: interaction platforms for cellular signalling circuits // Trends Cell Biol.-2009.-19, N 8.-P. 364-374.

2. Shaw A. S., Filbert E. L. Scaffold proteins and immune-cell signalling // Nat. Rev. Immunol.-2009.-9, N 1.-P. 47-56.

3. Tsyba L., Nikolaienko O., Dergai O., Dergai M., Novokhatska O., Skrypkina I., Rynditch A. Intersectin multidomain adaptor proteins: regulation of functional diversity // Gene.-2011.-473, N 2.-P. 67-75.

4. O'Bryan J. P. Intersecting pathways in cell biology // Sci. Signal.2010.-3, N 152.-re10.

5. Hunter M. P., Nelson M., Kurzer M., Wang X., Kryscio R. J., Head E., Pinna G., O'Bryan J. P. Intersectin 1 contributes to phenotypes in vivo: implications for Down Syndrome // Neuroreport.-2011.-22, N 15.-P. 767-772.

6. Wilmot B., McWeeney S. K., Nixon R. R., Montine T. J., Laut J., Harrington C. A., Kaye J. A., Kramer P. L. Translational gene mapping of cognitive decline // Neurobiol. Aging.-2008.-29, N 4.- P. 524-541.

7. Keating D. J., Chen C., Pritchard M. A. Alzheimer's disease and endocytic dysfunction: clues from the Down syndrome-related proteins, DSCR1 and ITSN 1 // Ageing Res. Rev.-2006.-5, N 4.P. 388-401.

8. Guipponi M., Scott H. S., Chen H., Schebesta A., Rossier C., Antonarakis $S$. E. Two isoforms of human intersectin (ITSN) protein are produced by brain-specific alternative splicing in a stop codon // Genomics.-1998.-53, N 3.-P. 369-376.

9. Pucharcos C., Casas C., Nadal M., Estivill X., de la Luna S. The human intersectin genes and their spliced variants are differentially expressed // Biochim. Biophys. Acta.-2001.-1521, N 1-3.P. 1-11.

10. Hussain N. K., Jenna S., Glogauer M., Quinn C. C., Wasiak S., Guipponi M., Antonarakis S. E., Kay B. K., Stossel T. P., Lamarche-Vane N., McPherson P. S. Endocytic protein intersectin-1 regulates actin assembly via Cdc42 and N-WASP // Nat. Cell. Biol.-2001.-3, N 10.-P. 927-932.

11. Novokhatska O., Dergai M., Houssin N., Tsyba L., Moreau J., Rynditch A. Intersectin 2 nucleotide exchange factor regulates Cdc42 activity during Xenopus early development // Biochem. Biophys. Res. Commun.-2011.-408, N 4.-P. 663-668.

12. Rodriguez-Fraticelli A. E., Vergarajauregui S., Eastburn D. J., Datta A., Alonso M. A., Mostov K., Martin-Belmonte F. The Cdc42 GEF Intersectin 2 controls mitotic spindle orientation to form the lumen during epithelial morphogenesis // J. Cell. Biol.2010.-189, N 4.-P. 725-738.

13. Nishimura T., Yamaguchi T., Tokunaga A., Hara A., Hamaguchi T., Kato K., Iwamatsu A., Okano H., Kaibuchi K. Role of numb in dendritic spine development with a Cdc42 GEF intersectin and EphB2 // Mol. Biol. Cell-2006.-17, N 3.-P. 1273-1285.

14. Thomas S., Ritter B., Verbich D., Sanson C., Bourbonniere L., McKinney R. A., McPherson P. S. Intersectin regulates dendritic spine development and somatodendritic endocytosis but not synaptic vesicle recycling in hippocampal neurons // J. Biol. Chem.2009.-284, N 18.-P. 12410-12419.

15. Sengar A. S., Wang W., Bishay J., Cohen S., Egan S. E. The EH and $\mathrm{SH} 3$ domain Ese proteins regulate endocytosis by linking to dynamin and Eps15 // EMBO J.-1999.-18, N 5.-P. 1159-1171. 
16. Okamoto M., Schoch S., Sudhof T. C. EHSH1/intersectin, a protein that contains $\mathrm{EH}$ and $\mathrm{SH} 3$ domains and binds to dynamin and SNAP-25 // J. Biol. Chem.-1999.-274, N 26.-P. 1844618454.

17. Yamabhai M., Hoffman N. G., Hardison N. L., McPherson P. S., Castagnoli L., Cesareni G., Kay B. K. Intersectin, a novel adaptor protein with two Eps 15 homology and five Src homology 3 domains // J. Biol. Chem.-1998.-273, N 47.-P. 31401-31407.

18. Pechstein A., Bacetic J., Vahedi-Faridi A., Gromova K., Sundborger A., Tomlin N., Krainer G., Vorontsova O., Schafer J. G., Owe S. G., Cousin M. A., Saenger W., Shupliakov O., Haucke V. Regulation of synaptic vesicle recycling by complex formation between intersectin 1 and the clathrin adaptor complex AP2 // Proc. Natl Acad. Sci. USA-2010.-107, N 9.-P. 4206-4211.

19. Dergai O., Novokhatska O., Dergai M., Skrypkina I., Tsyba L., Moreau J., Rynditch A. Intersectin 1 forms complexes with SGIP1 and Reps 1 in clathrin-coated pits // Biochem. Biophys. Res. Commun.-2010.-402, N 2.-P. 408-413.

20. Koh T.W., Verstreken P., Bellen H. J. Dap160/intersectin acts as a stabilizing scaffold required for synaptic development and vesicle endocytosis // Neuron.-2004.-43, N 2.-P. 193-205.

21. Marie B., Sweeney S. T., Poskanzer K. E., Roos J., Kelly R. B., Davis $G$. W. Dap160/intersectin scaffolds the periactive zone to achieve highfidelity endocytosis and normal synaptic growth // Neuron.-2004.-43, N 2.-P. 207-219.

22. Yu Y., Chu P. Y., Bowser D. N., Keating D. J., Dubach D., Harper I., Tkalcevic J., Finkelstein D. I., Pritchard M. A. Mice deficient for the chromosome 21 ortholog ItsN 1 exhibit vesicletrafficking abnormalities // Hum. Mol. Genet.-2008.-18, N 2.P. 3281-3290.

23. Henne W. M., Boucrot E., Meinecke M., Evergren E., Vallis Y., Mittal R., McMahon H. T. FCHo proteins are nucleators of clathrin-mediated endocytosis // Science.-2010.-328, N 5983.P. 1281-1284.

24. Malacombe M., Ceridono M., Calco V., Chasserot-Golaz S., McPherson P. S., Bader M. F., Gasman S. Intersectin-1L nucleotide exchange factor regulates secretory granule exocytosis by activating Cdc42 // EMBO J.-2006.-25, N 15.-P. 3494-3503.

25. Momboisse F., Ory S., Ceridono M., Calco V., Vitale N., Bader M. F., Gasman $S$. The Rho guanine nucleotide exchange factors Intersectin $1 \mathrm{~L}$ and $\beta$-Pix control calcium-regulated exocytosis in neuroendocrine PC12 cells // Cell Mol. Neurobiol.-2010.-30, N 8.-P. 1327-1333.

26. Sorkin A., Goh L. K. Endocytosis and intracellular trafficking of ErbBs // Exp. Cell Res.-2009.-315, N 4.-P. 683-696.

27. O'Bryan J. P., Mohney R. P., Oldham C. E. Mitogenesis and endocytosis: what's at the INTERSECTIoN? // Oncogene.-2001.20, N 44.-P. 6300-6308.

28. McPherson P. S., Kay B. K., Hussain N. K. Signaling on the endocytic pathway // Traffic.-2001.-2, N 6.-P. 375-384.

29. Chen P. H., Chien F. C., Lee S. P., Chan W. E., Lin I. H., Liu C. S., Lee F. J., Lai J. S., Chen P., Yang-Yen H. F., Yen J. J. Identification of a novel function of the clathrin-coated structure at the plasma membrane in facilitating GM-CSF receptor-mediated activation of JAK2 // Cell Cycle.-2012.-11, N 19.-P. 3611-3626.

30. Martin N. P., Mohney R. P., Dunn S., Das M., Scappini E., O'Bryan J. $P$. Intersectin regulates epidermal growth factor receptor endocytosis, ubiquitylation, and signaling // Mol. Pharmacol.2006.-70, N5.-P. 1643-1653.

31. Nikolaienko O. V., Skrypkina I. Ya., Tsyba L. O., Drobot L. B., Rynditch $A$.V. ITSN 1 and Ruk/CIN85 colocalized to clathrin- coated pits in MCF-7 cells // Biopolym. Cell.-2009.-25, N 5.P. 424-427.

32. Nikolaienko O. V., Skrypkina I. Ya, Dergay O. V., Matskova L., Tsyba L. O., Dergay M. V., Kropivko S. V., Winberg G., Rynditch $A$. $V$. Cbl family proteins are new binding partners of intersectin 1 // Factors of experimental evolution of organisms.Kiev: Logos, 2006-Vol. 3.-P. 122-127.

33. Okur M. N., Ooi J., Fong C. W., Martinez N., Garcia-Dominguez C., Rojas J. M., Guy G., O’Bryana J. P. Intersectin 1 enhances $\mathrm{Cbl}$ ubiquitylation of epidermal growth factor receptor through regulation of Sprouty2-Cbl interaction // Mol. Cell. Biol.-2012.32, N 4.-P. 817-825.

34. Novokhatska O. V., Skrypkina I. Ya., Dergai M. V., Tsyba L. O., Rynditch $A$. $V$. RTK signaling regulator SPRY2 associates with endocytic adaptor ITSN 1 in vivo // Biopolym. Cell.-2012.-28, N 4.-P. 314-316.

35. Nikolaienko O., Skrypkina I., Tsyba L., Fedyshyn Y., Morderer D., Buchman V., de la Luna S., Drobot L., Rynditch A. Intersectin 1 forms a complex with adaptor protein Ruk/CIN85 in vivo independently of epidermal growth factor stimulation // Cell. Signal.-2009.-21, N 5.-P. 753-759.

36. Teckchandani A., Mulkearns E. E., Randolph T. W., Toida N., Cooper J. A. The clathrin adaptor Dab2 recruits EH domain scaffold proteins to regulate integrin $\beta 1$ endocytosis mutations // Mol. Biol. Cell.-2012.-23, N 15.-P. 2905-2916.

37. Predescu S. A., Predescu D. N., Knezevic I., Klein I. K., MalikA. $B$. Intersectin-1s regulates the mitochondrial apoptotic pathway in endothelial cells // J. Biol. Chem.-2007.-282, N23.-P. 1716617178.

38. Bardita C., Predescu D.N, Justice M. J., Petrache I., Predescu $S$. In vivo knockdown of intersectin-1s alters endothelial cell phenotype and causes microvascular remodeling in the mouse lungs // Apoptosis.-2013.-18, N 1.-P. 57-76.

39. Das M., Scappini E.,Martin N. P., Wong K. A., Dunn S., Chen Y. J., Miller S. L., Domin J., O'Bryan J. P. Regulation of neuron survival through an intersectin-phosphoinositide 3'-kinase C2betaAKT pathway// Moll. Cell. Biol.-2007.-27, N 22.-P. 7906-7917.

40. Wong K. A., Wilson J., Russo A., Wang L., Okur M. N., Wang X., Martin N. P., Scappini E., Carnegie G. K., O'Bryan J. P. Intersectin (ITSN) family of scaffolds function as molecular hubs in protein interaction networks // PLoS One.-2012.-7, N 4.-e36023.

41. Tsyba L., Skrypkina I., Rynditch A., Nikolaienko O., Ferenets G., Fortna A., Gardiner K. Alternative splicing of mammalian Intersectin 1: domain associations and tissue specificities // Genomics.-2004.-84, N 1.-P. 106-113.

42. Kropyvko S., Gerasymchuk D., Skrypkina I., Dergai M., Dergai O., Nikolaienko O., Rynditch A., Tsyba L. Structural diversity and differential expression of novel human intersectin 1 isoforms // Mol. Biol. Rep.-2010.-37, N 6.-P. 2789-2796.

43. Tsyba L., Gryaznova T., Dergai O., Dergai M., Skrypkina I., Kropyvko S., Boldyryev O., Nikolaienko O., Novokhatska O., Rynditch $A$. Alternative splicing affecting the SH3A domain controls the binding properties of intersectin 1 in neurons // Biochem. Biophys. Res. Commun.-2008.-372, N 4.-P. 929-934.

44. Dergai M., Skrypkina I., Dergai O., Tsyba L., Novokhatska O., Filonenko V., Drobot L., Rynditch A. Identification and characterization of a novel mammalian isoform of the endocytic adaptor ITSN 1 // Gene.-2011.-485, N 2.-P. 120-129.

45. Dergai M., Tsyba L., Dergai O., Zlatskii I., Skrypkina I., Kovalenko $V$., Rynditch $A$. Microexon-based regulation of ITSN 1 and $\mathrm{Src} \mathrm{SH} 3$ domains specificity relies on introduction of char- 
ged amino acids into the interaction interface // Biochem. Biophys. Res. Commun.-2010.-399, N 2.-P. 307-312.

46. McGlincy N. J., Smith C. W. Alternative splicing resulting in nonsense-mediated mRNA decay: what is the meaning of nonsense? // Cell.-2008.-33, N 8.-P. 385-393.

47. Kropyvko S. V., Tsyba L. O., Skrypkina I. Ya., Rynditch A. V. Identification and functional analysis of an alternative promoter of human intersectin 1 gene // Biopolym. Cell.-2010.-26, N 2.P. 115-120.

48. Pucharcos C., Fuentes J. J., Casas C., de la Luna S., Alcantara S., Arbones M. L., Soriano E., Estivill X., Pritchard M. Alu-splice cloning of human Intersectin (ITSN), a putative multivalent binding protein expressed in proliferating and differentiating neurons and overexpressed in Down syndrome // Eur. J. Hum. Genet.1999.-7, N 6.-P. 704-712.

49. Skrypkina I., Tsyba L. O., Nikolaienko O. V., Kropivko S. V., Sopko N. I., Nikitchina T. V., Gordienko I. Yu., Rynditch A. V. Expression of intersectin 1 transcription isoforms in normal and Down syndrome tissues // Bull. Gov. Found. Fund. Invest. of the Ukraine.-2005.-P. 7-22.

50. Scappini E., Koh T. W., Martin N. P., O'Bryan J. P. Intersectin enhances huntingtin aggregation and neurodegeneration through activation of c-Jun- $\mathrm{NH}_{2}$-terminal kinase (JNK) // Hum. Mol. Genet.-2007.-16, N 15.-P. 1862-1871.

51. Morderer D., Nikolaienko O., Skrypkina I., Cherkas V., Tsyba L., Belan P., Rynditch A. Endocytic adaptor protein intersectin 1 forms a complex with microtubule stabilizer STOP in neurons // Gene.-2012.-505, N 2.-P. 360-364.

52. Andrieux A., Salin P. A., Vernet M., Kujala P., Baratier J., GoryFaure S., Bosc C., Pointu H., Proietto D., Schweitzer A., Denarier E., Klumperman J., Job D. The suppression of brain cold-stable microtubules in mice induces synaptic defects associated with neuroleptic-sensitive behavioral disorders // Genes Dev.-2002.16, N 18.-P. 2350-2364.
53. Alto N. M., Orth K. Subversion of cell signaling by pathogens // Cold Spring Harb. Perspect. Biol.-2012.-4, N 9.-a006114.

54. Dergai O., Dergai M., Skrypkina I., Matskova L., Tsyba L., Gudkova D., Rynditch A. The LMP2A protein of Epstein-Barr virus regulates phosphorylation of ITSN 1 and Shb adaptors by tyrosine kinases // Cell. Signal.-2013.-25, N 1.-P. 33-40.

55. Ma Y., Wang B., Li W., Ying G., Fu L., Niu R., Gu F. Reduction of intersectiN 1-s induced apoptosis of human glioblastoma cells // Brain Res.-2010.-1351.-P. 222-228.

56. Ma Y., Wang B., Li W., Liu X., Wang J., Ding T., Zhang J., Ying G., Fu L., Gu F. Intersectin 1-s is involved in migration and invasion of human glioma cells // J. Neurosci. Res.-2011.-89, N 7.P. 1079-1090.

57. Russo A., O'Bryan J. P. Intersectin 1 is required for neuroblastoma tumorigenesis // Oncogene.-2012.-31, N 46.-P. 4828-4834.

58. Specht K., Harbeck N., Smida J., Annecke K., Reich U., Naehrig J., Langer R., Mages J., Busch R., Kruse E., Klein-Hitpass L., Schmitt M., Kiechle M., Hoefler H. Expression profiling identifies genes that predict recurrence of breast cancer after adjuvant CMF-based chemotherapy // Breast Cancer Res. Treat.-2009.118, N 1.-P. 45-56.

59. Kriachok I. A., Syvak L. A., Gubareva G. O., Lialkin S. A., Maidanevych N. M., Klimanov M. Yu., Askolskiy A. V., Kasap N. V., Smolanka I. I., Graboviy O. M., Tsyba L. O., Novokhatska O. V., Kropyvko $S$. V., Rynditch A. V. Role of intersectin 2 in prognosis of breast cancer // Clinichna oncolohia (Ukraine).-2012.-4, N 8.- P. $158-160$. 